\title{
ЗАСТОСУВАННЯ МІЖНАРОДНИХ СТАНДАРТІВ ФОРМУВАННЯ НАЛЕЖНИХ ДОКАЗІВ У ПРАКТИЦІ ВІТЧИЗНЯНИХ СУДІВ
}

\section{КРЕТ Галина Романівна - кандидат юридичних наук, доцент, суддя Касаційного кримінального суду у складі Верховного Суду \\ DOI:10.32782/NP.2020.1.15 \\ УДК 342.727}

Статья посвящена исследованию международнъхх стандартов бормирования относимьхх доказательств, применяемьхх в практике отечественных судов. С точки зрения указанных стандартов анализируется практика судов первой инстанции в части оценки относимости доказательств и отражения ее результатов в судебных решениях. В контексте международньх стандартов бормирования относимых доказательств определяются особенности оценки доказательств с точки зрения их относимости, осуществляемой судами апелляционной инстанции, и мотивировки оснований признания доказательств относимьими/неотносимьлми в их судебных решениях. Приводятся отдельньие правовъе позищии суда кассащионной инстанции в части обоснованности оценки относимости доказательств, осуществленной судами первой и апеллячионной инстанщий. C учетом практики отечественнъхх судов определяются особенности применения ими международнъхх стандартов бормирования относимъих доказательств.

Ключевъе слова: стандарть доказивания, международнье стандарть доказьвания, стандарть формирования относимъхх доказательств, относимость доказательств, относимъе доказательства, начиональные cyдъı.

\section{Вступ}

Міжнародні стандарти формування належних доказів знайшли закріплення у вітчизняному кримінальному процесуально- му законі та широке використання у практиці національних судів. Впровадження вказаних стандартів доказування у вітчизняне кримінальне процесуальне законодавство відбулося 3 прийняттям чинного КПК України, який закріпив поняття належних доказів (ст. 85), поклав на суб'єктів доказування обов'язок здійснення оцінки доказів із точки зору їх належності (ч. 1 ст. 94 КПК України) і врегулював окремі питання, пов'язані з формуванням належних доказів стороною захисту, потерпілим, представником юридичної особи, щодо якої здійснюється провадження, доведенням сторонами кримінального провадження належності доказів перед судом i відображенням мотивів визнання окремих доказів неналежними в ухвалі суду апеляційної інстанції (ч. 2 ст. 92, ч. 3 ст. 93 і п. 2 ч. 1 ст. 419) [13].

У доктрині кримінального процесу дослідженню поняття та змісту стандартів доказування й особливостей їх застосування у судовій практиці присвячена істотна увага вчених-процесуалістів. Зокрема, вказана проблематика розкривається у працях В.Д. Басая, В.В. Вапнярчука, І.В. Гловюк, В.О. Гринюка, В.А. Завтура, С.О. Ковальчука, В.I. Мариніва, М.А. Погорецького, Х.Р. Слюсарчук, А.С. Степаненка, В.М. Трофименка, О.Г. Шило та інших вітчизняних і зарубіжних вчених. Проте, науковці лише фрагментарно звертаються до дослідження особливостей застосування вітчизняними судами напрацьованих у 
практиці Европейського Суду з права людини стандартів формування достатньої сукупності належних, допустимих і достовірних доказів.

\section{Постановка завдання}

Метою статті $\epsilon$ розкриття на основі практики вітчизняних судів особливостей застосування міжнародних стандартів формування належних доказів.

\section{Результати дослідження}

Загальні положення стосовно здійснення оцінки доказів закріплені у ч. 1 ст. 94 КПК України, згідно з якою слідчий, прокурор, слідчий суддя, суд за своїм внутрішнім переконанням, яке грунтується на всебічному, повному й неупередженому дослідженні всіх обставин кримінального провадження, керуючись законом, оцінюють кожний доказ з точки зору належності, допустимості, достовірності, а сукупність зібраних доказів - з точки зору достатності та взаємозв'язку для прийняття відповідного процесуального рішення [13]. Наведена норма значною мірою корелюється зі сформованим ЕСП $\Lambda$ міжнародним стандартом доказування, відповідно до якого оцінка доказів 3 точки зору їх належності виступає обов'язком національних судів.

У практиці вітчизняних судів належність доказів оцінюється під час судового розгляду в першій інстанції та апеляційного провадження. Подання доказів сторонами кримінального провадження зобов'язує суди першої та апеляційної інстанцій безпосередньо дослідити їх і надати оцінку кожному 3 них 3 точки зору належності шляхом 3'ясування їх значимості для встановлення фактів/обставин кримінального провадження та відобразити результати цієї оцінки у судовому рішенні.

Тягар доказування належності доказів, 3 огляду на норму ч. 2 ст. 92 КПК України, покладається на сторону, що їх подає [13]. Стосовно сторони захисту такий підхід законодавця пояснюється наданням їй, як і потерпілому та представнику юридичної особи, щодо якої здійснюється провадження, права збирати доказів шляхом здійснення дій, які здатні забезпечити подан- ня суду належних доказів (ч. 3 ст. 93 КПК України) [13] та відповідає міжнародному стандарту доказування, який передбачає покладення на сторону захисту тягаря доказування належності доказів, які подаються нею або про отримання яких нею заявлено клопотання.

Відповідно, суди першої та апеляційної інстанцій вправі визнати досліджений у ході судового розгляду доказ належним за умови доведення стороною кримінального провадження, яка подала його суду, відповідності цього доказу вимогам ст. 85 КПК України. I, навпаки, невиконання стороною кримінального провадження обов'язку підтвердити належність поданого нею доказу призводить до визнання його неналежним.

Як свідчать результати дослідження судової практики, вирішуючи питання про належність доказів, переважна більшість судів першої інстанції наводить у своїх судових рішеннях докази, які підтверджують наявність/відсутність тих або інших обставин, які становлять предмет доказування у кримінальному провадженні. При цьому одні суди констатують належність наявних доказів у цілому, вказуючи на те, що вони містять у собі фактичні дані, які логічно пов'язані з тими обставинами, що підлягають доказуванню в справі та становлять предмет доказування [1;9; 10]. Інші суди, здійснюючи оцінку досліджених ними у ході судового розгляду доказів, визначають належність кожного 3 них шляхом чіткої вказівки на встановлені за його допомогою ті або інші обставини, які входять у предмет доказування у конкретному кримінальному провадженні [2; 6; 8]. Аналіз наведених позицій у контексті норм кримінального процесуального закону дозволяє стверджувати, що саме остання 3 них чітко відповідає вимогам як ч. 1 ст. 94 КПК України, в якій належність доказів закріплюється як їх індивідуальна властивість, так і ч. 3 ст. 370 КПК України, яка пов'язує обгрунтованість судових рішень 3 об'єктивно з'ясованими обставинами, які підтверджені доказами, дослідженими під час судового розгляду та оціненими судом відповідно до ст. 94 КПК України [13]. 


\section{Кримінальне право, кримінальний процес та криміналістика}

Оцінюючи докази із точки зору їх належності, національні суди, керуючись ст. 85 КПК України, не лише встановлюють їх прямий або опосередкований зв'язок 3 обставинами, що підлягають доказуванню у кримінальному провадженні, та іншими обставинами, які мають значення для кримінального провадження, але й визначають можливість використання оцінюваних доказів для встановлення достовірності чи недостовірності, можливості чи неможливості використання інших доказів. Так, Кагарлицький районний суд Київської області під час судового розгляду справи № 368/94/18 (провадження № 1-кп/368/25/19) дослідив документ - лист-інформацію Кагарлицького відділення поліції Обухівського ВП ГУ НП в Київській області за № 738/109/1009.1/01-19 від 25.02.2019 р. (том № 2, а. с. 35), в якому вказувалося, що відповідно до Книги нарядів Кагарлицького відділення поліції Обухівського ВП ГУ НП України в Київській області (інвентарний № 105 від 05.09.2017 р.) на добове чергування 28.09.2017 р. до складу слідчо-оперативної групи заступили: слідчий ОСОБА_25, оперуповноважений ОСОБА_12 та експерт-криміналіст ОСОБА_32. Надаючи оцінку цьому доказу у вироку від 18.06.2019 р., суд визнав його неналежним для підтвердження вини обвинуваченого у вчиненні злочину, передбаченого ч. 2 ст. 309 КК України. Поряд із цим, суд вказав на належність цього доказу для спростування показань свідка ОСОБА 15 , який, 3 його слів, нібито був експертом під час проведення обшуку в домогосподарстві обвинуваченого ОСОБА_1. Як вбачається з вищевказаної довідки, експертом у складі слідчо-оперативної групи, яка виїздила на місце обшуку, була інша особа - експерткриміналіст ОСОБА_32, що підтвердили у судовому засіданні слідчий ОСОБА_25, допитаний як свідок, і свідок ОСОБА_17 [4].

У разі визнання доказів неналежними суди першої інстанції наводять мотиви такого рішення. Так, Кагарлицький районний суд Київської області визнав у вироку від 18.06.2019 р. у справі № 368/94/18 (провадження № $1-\kappa п / 368 / 25 / 19)$ низку доказів, поданих стороною обвинувачен- ня неналежними, у тому числі й витяг 3 ЕРДР від 28.09.2017 р. (том № 1, а. с. 62), стосовно якого зазначив, що суд не вважає його належним доказом для підтвердження винуватості обвинуваченого ОСОБА_1 у вчиненні ним злочину, передбаченого ч. 2 ст. 309 КК України. Свою позицію суд обгрунтував тим, що вказаний доказ доводить лише ту обставину, що реєстратор, у розумінні ЕРДР, - начальник слідчого відділення Кагарлицького відділення Обухівського ВП ГУ НП в Київській області ОСОБА_30 - формально дотримався положень ст. 214 КПК України, у частині внесення до ЕРДР відомостей - рапорту оперуповноваженого Кагарлицького відділення Обухівського ВП ГУ НП в Київській області старшого лейтенанта поліції ОСОБА_17, так як у вищевказаному рапорті містяться ознаки вчинення злочину, передбаченого ч. 1 ст. 309 КК України, проте, суд ще раз наголошує на тій обставині, що існування такого витягу з ЕРДР ніяким чином не підтверджує факт вчинення цього правопорушення саме обвинуваченим ОСОБА_1 [4].

Крім того, результати дослідження судової практики свідчать про визнання судами першої інстанції доказів неналежними у частині, що виходить за межі висунутого обвинувачення, зазначеного в обвинувальному акті, якщо їх використання може призвести до погіршення становища обвинуваченого. Зокрема, Саксаганський районний суд м. Кривого Рогу Дніпропетровської області у вироку від 05.07.2018 р. у справі № 214/770/18 (провадження № 1-кп/214/458/18) вказав, що враховуючи вимоги ч. ч. 1 і 3 ст. 337 КПК України, він вважає, що показання свідка ОСОБА_18 у тій частині, що ОСОБА_12 направляв пістолет на ОСОБА_17, що ОСОБА_12 говорив ОСОБА_17, що якщо їм не надати гроші, то ОСОБА_17 піде наступного дня на роботу з однією ногою, що напад був вчинений як на неї, так і на ОСОБА_17, є неналежним доказом, оскільки вказані обставини виходять за межі обвинувачення, висунутого обвинуваченим, можуть бути підставою для зміни обвинувачення, що погіршить становище обвинувачених, а тому показання свідка ОСОБА_18 у цій 
частині не враховує [7].

Як і суди першої інстанції, суди апеляційної інстанції надають оцінку доказам із точки зору належності за умови їх безпосереднього дослідження під час апеляційного розгляду. Як відзначає С.О. Ковальчук, здійснена судом першої інстанції оцінка доказів не виступає обов'язковою для суду апеляційної інстанції, оскільки останній, грунтуючись на результатах безпосереднього дослідження доказів, вправі дати їм власну оцінку. У разі, якщо судом апеляційної інстанції дослідження доказів не проводилося, здійснювана ним оцінка доказів обмежується їх оцінкою судом першої інстанції [1 1, с. 387] та повинна відповідати їй. Така позиція узгоджується з правовими позиціями, які свого часу висловлювалися Верховним Судом України у ч. 5 п. 5 постанови Пленуму від 15.05 .2006 р. № 1 , відповідно до якої виходячи 3 принципу безпосередності дослідження доказів, апеляційний суд не вправі дати їм іншу оцінку, ніж та, яку дав суд першої інстанції, якщо їх не було досліджено під час апеляційного розгляду справи [16]. Поряд із вказаною постановою Пленуму, наведена позиція використовувалася Верховним Судом України у його судових рішеннях (зокрема, постанові від 21.01.2016 р. у справі № 5-249кс15) [15]. На сьогодні до питання оцінки судом апеляційної інстанції доказів, отриманих під час судового розгляду судом першої інстанції та безпосередньо недосліджених у ході апеляційного провадження, звертається Верховний Суд, який, зокрема, у постанові від 17.05.2018 p. у справі № 480/1877/16-к (провадження № 51-3047км 18) відзначає, що згідно $з$ доктринальними положеннями кримінального процесуального права при апеляційному перегляді у суду не виникає обов'язку досліджувати всю сукупність доказів із дотриманням засади безпосередності, якщо він по-новому (інакше) не тлумачить докази, отримані в суді першої інстанції, однак якщо апеляційний суд переоцінює хоча 6 один доказ, здобутий у суді першої інстанції, він повинен безпосередньо дослідити всі інші докази з дотриманням вимог ст. 23 КПК України [14].
Надання судом апеляційної інстанції за результатами безпосереднього дослідження доказів їх оцінки із точки зору належності, відмінної від наданої ім оцінки судом першої інстанції, пов'язане зі встановленням ним неповноти судового розгляду та невідповідності висновків суду першої інстанції фактичним обставинам кримінального провадження як підстав для скасування або зміни судового рішення судом апеляційної інстанції (п. п. 1 і 2 ст. 409, ст. ст. 410 і 411 КПК України). Так, під час судового розгляду справи № 7558/3591/15-к (провадження № 11-кп/824/72/2018), Київський апеляційний суд за клопотанням прокурора безпосередньо дослідив наявні в матеріалах кримінального провадження докази, у тому числі й документи і висновки експерта, визнані судом першої інстанції неналежними із тих мотивів, що вони не несуть доказової інформації щодо особи, яка вчинила злочин. Суд апеляційної інстанції не погодився 3 таким висновком суду першої інстанції та визнав у вироку від 28.12.2018 р. зазначені докази належними, з огляду на наступне. Зокрема, відомість обліку закріплення зброї, затверджена командиром в/ч 3027 OCOБА_18, підтверджує належність потерпілому ОСОБА_4 автомата АКС-74 НОМЕР_1, який був викрадений та в подальшому виявлений поблизу місця, де був затриманий ОСОБА_1. Згідно з висновком балістичної експертизи від 12.02.2015 р. № 105, предмет, схожий на автомат, що був вилучений 11.02 .2015 р. під час огляду місця події по вул. Вишгородській, 21 у м. Києві, є військовою вогнепальною зброєю - нарізним автоматом «АКС-74», НОМЕР_1, калібру 5,45x39 мм, виробництва СРСР та придатний до стрільби. Висновком товарознавчої експертизи від 20.02.2015 р. № 79тв встановлена залишкова вартість bluetoothгарнітури марки «Jabra Talk», яка станом на 11.02.2015 р. могла становити 594 гривні. Аналізуючи дані докази, суд звернув увагу на встановлені під час судового розгляду обставини, сукупність яких беззаперечно вказує на причетність ОСОБА_1 до вчинення інкримінованих йому злочинів. У першу чергу, суд відзначив схожість 


\section{Кримінальне право, кримінальний процес та криміналістика}

прикмет особи, яка за показаннями свідків ОСОБА_6 та ОСОБА_7, вчинила крадіжку, та ОСОББА_1 під час затримання. Шляхом експертного дослідження слідів папілярних узорів, знайдених на дверях автомобіля «Mercedes Vito», встановлено, що ці двері відчиняв ОСОБА_1. До затримання обвинуваченого свідок ОСОБА_17 також бачив особу, одягнену в світлу кутку і темні штани, яка несла предмет, схожий на автомат. Саме на підставі його показань одразу ж було затримано ОСОБА 1. Поряд з ним було знайдено викрадений автомат, а при ньому bluetooth-гарнітуру, яка належить потерпілому і знаходилась в автомобілі. Працівники поліції ОСОБА_12 та ОСОБА_13, які здійснювали затримання ОСОБА_1, вказали, що під час наближення до підозрюваних чоловік в білій куртці відкинув якийсь предмет, а при його затриманні за декілька метрів на залізній решітці виявили автомат, серійний номер якого відповідав номеру тієї зброї, яка була закріплена за ОСОБА_4. Сукупність поданих стороною обвинувачення доказів спростовує показання свідків ОСОБА_19, ОСОБА_20 та ОСОБА_21, на які посилається сторона захисту в обгрунтування невинуватості ОСОБА_1, у зв'язку з чим суд апеляційної інстанції не бере їх до уваги. 3 урахуванням викладеного, суд скасував виправдувальний вирок Подільського районного суду м. Києва від 19.09.2017 р., ухвалений щодо ОСОБА_1, та ухвалив новий вирок, яким ОСОБА 1 визнав винним у вчиненні злочинів, передбачених ч. 1 ст. 262, ч. 1 ст. 263, ч. 2 ст. 185 КК України [5].

Особливу увагу національні суди звертають на належність доказів, які подаються стороною захисту, та вправі відмовити їй у поданні доказів або задоволенні клопотання про їх отримання лише у разі визнання таких доказів неналежними. Так, Голосіївський районний суд м. Києва у вироку від 18.04.2016 р. у справі № 752/15787/15-к (провадження №: 1-кп/752/168/16) визнав неналежними подані стороною захисту докази - висновок спеціаліста і документи (топографічні карти). При цьому суд вказав, що як доказ стороною захисту надано висновок спеціаліста від 11.12.2015 p.
№ 277/15, виконаний спеціалістом ОСОБА_53 на запит сторони захисту, а також переглянутий відеозапис роз'яснення зазначеного спеціаліста в обгрунтування позиції на предмет того, що військовослужбовцю Збройних Сил України ОСОБА_14 смертельне вогнепальне поранення голови могло бути заподіяне кулею діаметром 0,5 - 0,6 см., тобто вогнепальною зброєю, в якій використовуються боєприпаси з кулями вказаного діаметру як, наприклад, автомат Калашникова і його модифікації, а не боєприпасами, спорядженими снарядом (кулею), діаметр якої може бути в межах 0,8 - 1,0 см., як зазначено у висновку експерта, який наданий стороною обвинувачення, тобто смертельне поранення ОСОБА_14 не міг заподіяти ОСОБА_54, який був озброєний гвинтівкою «Винторез». Однак, враховуючи ті обставини, що конкретно ОСОБА_9 та ОСОБА_10 не обвинувачуються у вбивстві ОСОБА_14, а їм було пред'явлено обвинувачення, яке знайшло своє підтвердження в суді, у вчиненні терористичного акту за попередньою змовою групою осіб, наслідком якого стала смерть ОСОБА_14, вищезазначений висновок ніяким чином не спростовує докази сторони обвинувачення на предмет того, що саме дії терористичної групи, до складу якої наряду з іншими невстановленими військовослужбовцями Збройних Сил Російської Федерації входили обвинувачені, призвели до загибелі військовослужбовця 92-ї окремої механізованої бригади ОСОБА_14. Надані стороною захисту карти 3 відміткою розмежування та існування у зв’язку з цим позиції на предмет того, що опорний пункт «Фасад» 92-ї окремої механізованої бригади Збройних Сил України знаходився на території, де не повинен був знаходитися за Мінськими домовленостями, суд до уваги не бере та відкидає як неналежні докази, оскільки вони непрямо підтверджують існування обставин, що підлягають доказуванню у зазначеному кримінальному провадженню, а дотримання Мінських домовленостей не є предметом зазначеного судового розгляду [3].

У разі відмови стороні захисту у поданні доказів або задоволенні клопотання про 
їх отримання національні суди повинні навести мотиви такого рішення, що відповідатиме гарантіям справедливого судового розгляду, закріпленим ст. 6 Конвенції про захист прав людини і основоположних свобод від 04.11.1950 р., ратифікованої Законом України від 17.07.1997 р. [12]. На це свого часу звернув увагу Верховний Суд України, який у постанові від 21.01.2016 р. у справі № 5-249кс15 вказав, що під час судового розгляду в суді апеляційної інстанції сторона захисту після допиту потерпілої ОСОБА_9 і спеціаліста ОСОБА_10 клопотала про відтворення аудіозапису їх показань у суді першої інстанції, оскільки, на ії переконання, зазначені особи змінили свої показання. Захисник також просив неодмінно допитати свідка ОСОБА_7 (про допит свідків ОСОБА_6 та ОСОБА_8 сторони судового провадження клопотань не заявляли), оскільки вважав, що їі показання є ключовими і висвітлюють істину у справі. Незважаючи на те, що кожен факт причетності особи до вчинення злочину та винності має бути підтверджений повнотою зібраних доказів, а переконливість кожного доказу доводиться у змагальній процедурі безпосередньо перед тим складом суду, який дає цьому доказу юридично значущу оцінку, апеляційний суд відхилив вимоги захисту без зазначення мотивів свого рішення. Апеляційний суд не допитав свідків ОСОБА_7 і ОСОБА_6 та відхилив їх показання як такі, що свідчать на користь обвинуваченого... Поза будь-яким сумнівом, хоч апеляційній інстанції належить давати оцінку різним зібраним показанням, так само як і визначати доцільність використання тих, що їх хотів навести захисник, проте глибшого аналізу не зроблено, а ОСОБА_3 визнано винним на підставі тих показань, які викликали достатні сумніви у місцевого суду щодо обгрунтованості висунутого проти ОСОБА_3 обвинувачення, і який на підставі цих показань мотивував його виправдання. За таких умов відмова апеляційного суду заслухати свідка ОСОБА_7, всупереч клопотанню адвоката щодо цього, та інша оцінка показань її та ОСОБА_6 без їх безпосереднього допиту суттєво обмежило право обвинуваченого на захист. Суд звертає увагу на те, що провадження у суді апеляційної інстанції проводилося через дванадцять років з моменту вчинення злочину, який було інкриміновано ОСОБА_3, а відтак кожний доказ (докази) мав бути чи не найголовнішим для встановлення істини у справі, тому відмова суду заслухати свідка ОСОБА_7 межувала 3 несправедливістю... Беручи до уваги виключно специфічні обставини цієї справи, Суд вважає, що право на захист зазнало такого обмеження, що засуджений ОСОБА_3 був позбавлений можливості скористатися справедливим судом, що суперечить положенням пунктів 1 та 3(d) статті 6 Конвенції [15].

Рішення про визнання доказів належними/неналежними приймаються судами під час ухвалення судових рішень, в яких ними відображаються висновки з питання належності/неналежності доказів. У разі визнання доказів неналежними суди першої інстанції зобов'язані навести у них мотиви такого рішення. Зазначений обов'язок судів першої інстанції грунтується на нормах п. п. 1 і 2 ч. 3 ст. 374 України, відповідно до яких у мотивувальній частині вироку у разі визнання особи виправданою зазначаються мотиви, з яких суд відкидає докази обвинувачення, а у разі визнання особи винуватою - мотиви неврахування окремих доказів [13]. Суди апеляційної інстанції зобов'язані навести мотиви визнання доказів належними/неналежними у разі надання їм оцінки, що відрізняється від оцінки суду першої інстанції. Так, згідно 3 ч. 2 ст. 420 КПК України, по-перше, вирок суду апеляційної інстанції повинен відповідати загальним вимогам до вироків, а подруге, у ньому зазначаються у тому числі мотиви ухваленого рішення [13], у тому числі щодо визнання доказів належними/ неналежними. Відповідно до п. 2 ч. 1 ст. 419 КПК України, у мотивувальній частині ухвали суду апеляційної інстанції підлягають зазначенню мотиви визнання окремих доказів неналежними [13].

\section{Висновки}

Проведене дослідження практики національних судів свідчить, що вони здійсню- 


\section{Кримінальне право, кримінальний процес та криміналістика}

ють оцінку належності доказів з урахуванням міжнародних стандартів формування належних доказів. Відповідно до вказаних стандартів, національні суди, по-перше, визнають оцінку доказів із точки зору ї належності своїм обов'язком, по-друге, забезпечують покладення на сторони кримінального провадження тягаря доказування належності доказів, які ними подаються, по-третє, з'ясовують значимість доказів для встановлення фактів/обставин кримінального провадження, по-четверте, забезпечують використання доказів для підтвердження достовірності чи недостовірності інших доказів, по-п'яте, піддають оцінці з точки зору належності як наявні докази, так і докази, які подаються стороною захисту або про отримання яких нею заявлено клопотання, по-шосте, відмовляють стороні захисту у поданні доказів або задоволенні клопотання про їх отримання лише у разі визнання таких доказів неналежними, по-сьоме, вказують на неприпустимість відмови стороні захисту у поданні доказів або задоволенні клопотання про їх отримання без обгрунтування неналежності доказів, по-восьме, відображають результати оцінки доказів із точки зору їх належності та іiі мотиви в ухвалюваних судових рішеннях.

\section{Лiтература}

1. Вирок Артемівського міськрайонного суду Донецької області від 05.11.2018 р. у справі № 219/10618/18 (провадження № 1-кп/219/967/2018). URL: http://www.reyestr. court.gov.ua/Review/77595021.

2. Вирок Великоолександрівського районного суду Херсонської області від 13.03.2019 р. у справі № 650/229/19 (провадження № 1-кп/650/83/19). URL: http:// www.reyestr.court.gov.ua/Review/80400011.

3. Вирок Голосіївського районного суду м. Києва від 18.04.2016 р. у справі № 752/15787/15-к (провадження №: 1-кп/752/168/16). URL: http://www.reyestr. court.gov.ua/Review/57301468.

4. Вирок Кагарлицького районного суду Київської області від 18.06.2019 p. у справі № 368/94/18 (провадження № 1-кп/368/25/19). URL: http://www.reyestr.
court.gov.ua/Review/82441553.

5. Вирок Київського апеляційного суду від 28.12.2018 р. у справі № 7558/3591/15к (провадження № 11-кп/824/72/2018). URL: http://www.reyestr.court.gov.ua/ Review/79083279.

6. Вирок Саксаганського районного суду м. Кривого Рогу Дніпропетровської області від 05.07.2018 р. у справі № 214/770/18 (провадження № 1-кп/214/458/18). URL: http:// www.reyestr.court.gov.ua/Review/75142949.

7. Вирок Саксаганського районного суду м. Кривого Рогу Дніпропетровської області від 29.11.2018 р. у справі № 214/7635/16-к (провадження № 1-кп/214/139/18). URL: http://www.reyestr. court.gov.ua/Review/78220843.

8. Вирок Слов'янського міськрайонного суду Донецької області від 26.03.2019 р. у справі № 243/1835/19 (провадження № 1-кп/243/418/2019). URL: http://www.reyestr. court.gov.ua/Review/80707726.

9. Вирок Трускавецького міського суду Аьвівської області від 18.12.2018 р. у справі № 457/968/18 (провадження № 1-кп/457/158/18). URL: http://www.reyestr. court.gov.ua/Review/78794741.

10. Вирок Центрально-Міського районного суду м. Кривого Рогу Дніпропетровської області від 03.04.2018 р. у справі № 216/806/17 (провадження № 1-кп/216/126/18). URL: http://www.reyestr. court.gov.ua/Review/73167924.

11. Ковальчук С.О. Вчення про речові докази у кримінальному процесі: теоретико-правові та практичні основи: монографія. Івано-Франківськ: Супрун В.П., 2017. $618 \mathrm{c}$.

12. Конвенція про захист прав людини i основоположних свобод від 04.11.1950 р., ратифікована Законом України від 17.07 .1997 p. № 475/97-BP. URL: http:// zakon.rada.gov.ua/laws/show/995_004.

13. Кримінальний процесуальний кодекс України від 13.04.2012 р. № 4651VI. URL: http://zakon5.rada.gov.ua/laws/ show/4651-17.

14. Постанова Верховного Суду від 17.05.2018 р. у справі № 480/1877/16-к (провадження № 51-3047км18). URL: http:// www.reyestr.court.gov.ua/Review/74262127. 
Крет Г.Р. - Застосування міжнародних стандартів формування належних доказів...

\section{АНОТАЦІЯ}

Стаття присвячена дослідженню міжнародних стандартів бормування належних доказів, які застосовуються у практиці вітиизняних судів. Із точки зору вказаних стандартів аналізується практика судів першой інстанцй щодо оцінки належності доказів $i$ відображення ї результатів у судових рішеннях. У контексті міжнародних стандартів бормування належних доказів визначаються особливості оцінки доказів із точки зору їх належності, здійснюваної судами апелячійної інстаниї, та мотивування підстав визнання доказів належними/неналежними в їх судових рішеннях. Наводяться окремі правові позииіи суду касаиійної інстаниій у частині обгрунтованості оцінки належності доказів, здійсненої судами першої та апеляиійної інстаниій. Iз урахуванням практики вітчизняних судів визначаються особливості застосування ними міжнародних стандартів бормування належних доказів.

Ключові слова: стандарти доказування, міжнародні стандарти доказування, стандарти фбормування належних доказів, належність доказів, належні докази, начіональні cydu.

15. Постанова Верховного Суду України від 21.01.2016 р. у справі № 5-249кс15. URL: $\quad$ http://www.reyestr.court.gov.ua/ Review/56580962.

16. Про практику постановлення судами вироків (постанов) при розгляді кримінальних справ в апеляційному порядку: Постанова Пленуму Верховного Суду України від 15.05.2006 р. № 1. URL: https:// zakon.rada.gov.ua/laws/show/v000170006\# Text.
The article is devoted to the research of the international standards for formation of the relevant evidences which are applied in practice of domestic courts. From the standpoint of these standards, the practice of the courts of first instance in assessing the relevance of evidences and reflecting its results in court decisions are analyzed. In the context of the international standards for the formation of relevant evidences, the specifics of the assessment of evidences in terms of their relevance by the courts of appeal and the reasons for the recognition of evidences as relevant/irrelevant in their judicial decisions are determined. Certain legal positions of the court of cassation in the part of the validity of the assessment of the relevance of the evidences made by the courts of first instance and courts of appeal are cited.

Taking into account the practice of national courts, the peculiarities of the application by them the international standards for formation of relevant evidences are determined. It is substantiated that, in accordance with these standards, the national courts, firstly, to recognize the assessment of evidences in terms of its relevance as their duty, secondly, to ensure that the burden of proving of the relevance of evidences produced by them is placed on the sides of criminal proceedings, thirdly, to determine the importance of evidences to establish the facts/circumstances of criminal proceedings, fourthly, to ensure the use of evidences to confirm the reliability or unreliability of other evidences, fifthly, to evaluate from the point of view of relevance both the available evidences and the evidences submitted by the defence side or for receipt of which it has made the petition, sixthly, to refuse the defence party to present evidences or satisfy the petition to receive it only if such evidences is considered irrelevant; seventhly, to point out the inadmissibility of the refusal to the defence side in the submission of evidences or in the satisfaction of the petition for its receipt without justification of the irrelevance of the evidences, eighthly, to reflect the assessment of evidences in terms of their relevance and its motives in the court decisions decided by them.

Keywords: standards of proof, international standards of proof, standards for formation of relevant evidences, relevance of evidences, relevant evidences, national courts. 